\title{
Panopticons Migrate too and Give Birth to Criminals: A Case Study of a Turkish Muslim "Sultan" in Elif Şafak's Honour*
}

\author{
Nour Seblini \\ Department of Classical and Modern Languages, Literatures and Cultures, Wayne State University \\ United States \\ nour.seblini@wayne.edu
}

\begin{abstract}
In this article, I use the insights of new historicism to comprehensively analyze Shafak's novel Honour (2012). I focus on the male protagonist, Iskender, as I aim to gain new insights on the phenomenon of honour killings by adding the "why" and "how" the crime is viewed through the lens of the perpetrator himself. And, I argue that the idea of honour is linked to communal surveillance. By communal surveillance, I mean that traditional codes from the killer's country of origin have been displaced into the migrant community. These displaced beliefs that do not fully fit in with the new British society nonetheless define the killer's notion of honour. I demonstrate how internalized surveillance encourages crime rather than hindering its commission while paradoxically it preserves the main concept of discipline and punish. Accordingly, honour killings are based on what I would call Foucault's "panopticon in reverse."
\end{abstract}

Keywords: Surveillance, International Migration, Panopticism, Honour Killings, Security INTRODUCTION

Discussions of honor killings often concentrate on the study of gender roles. In these debates, the controlled and sexualized female body which is being punished and/or penetrated by a male oppressor is emphasized. ${ }^{1}$ In contrast, the present article endorses a historicist approach to analyze the male protagonist, Iskender, in Şafak's novel Honour(2012). It goes beyond studying women as victims by adding the "why" and "how" the crime is viewed through the lens of the perpetrator himself to work on preventing the occurrence of future family murders.

The novel Honour (2012) is a story that narrates the cultural division experienced by the already culturally split Turkish-Kurdish family members. The family has migrated from a small village near the Euphrates to the capital city of their home country, Istanbul, and then to that of a foreign country, London, England. The text offers insights into the challenges immigrants face as they try to hold on to their traditional values while living in a modern British setting.

In modern societies, as the Foucauldian thinking reflects, there is a basic power/knowledge relationship that serves to generate citizens as active participants in self-regulating behavior (Sturken M. \& Luisa Cartwright, 2001). I am applying this idea to the city of London, specifically to the context of Turkish Muslim communities in London as represented in Şafak's novel. I aim to question the relevance of urban surveillance as well as the migrants' own surveillance system for honor killings and migrant behavior in general. And I argue that, what I will call, the "panopticon in reverse" is designed to guarantee that the members of the Turkish Muslim immigrant community preserve their native land's ethno-religious traditions while living in Western societies.

1 See the works ofAtabekyan (2013) and Demir (2012)

www.arjonline.org

Page 1 
Panopticons Migrate too and Give Birth to Criminals: A Case Study of a Turkish Muslim "Sultan" in Elif Şafak's Honour*

\section{ANALYSIS}

There exists systematic, psychological implementation of beliefs that cannot be enforced physically by the community on its members, but that work on having members themselves enforce the ideologies physically in society. Communal surveillance helps to control individual members. Because the community is not a police state or a dystopian authoritarian state but rather a group of individuals that talks and watches and judges, the kind of surveillance it exercises does not mean actual surveillance through spying, reporting, cameras, but rather it refers to the constant sense that somebody may be watching one without actual surveillance systems in place. By feeling that their behavior is constantly being watched, members are less likely to break traditional "customs" even when the upholding of these traditions is regarded as a criminal act under the laws of the larger host society, in this case, the British.

Communal surveillance dominates societal surveillance. Whether observation from the community occurs in reality or not is irrelevant, the mere belief of its presence is enough to influence members ensuring thereby that communal codes are obeyed. Under this model, individuality is suffocated, and only conformity is created. Members end up acting and being the same for fear of being punished. This exemplifies Foucault's concept of dynamic normalization. The message here is that discipline normalizes, differentiates between individuals in function of an already established norm, distinguishing on that basis, the normal from the abnormal and correcting the latter.

The reversal of the Foucault's discussion of the panopticon has to do with the objective part of the equation. Foucault states that, "The Panopticon, has a role of amplification; although it arranges power, although it is intended to make it more economic and more effective, it does so not for power itself, nor for the immediate salvation of a threatened society: its aim is to strengthen the social forces - to increase production, to develop the economy, spread education, raise the level of public morality; to increase and multiply." (Foucault, 195228). This repeats Bentham's talk regarding the rehabilitative part of the Panopticon and its role of improving the human condition in society. It is in here that the Turkish Muslim panopticon differs because- as depicted throughout the plot of Shafak's novel- its practice of surveillance disciplines the migrant protagonist in a way that leads him to commit a crime for fear of becoming an outcast in the community. This specific point shows that panopticism cannot be perceived as a universal concept, and that cultural differences need to be taken into account when applicability is in question.

Although the migrant communal panopticon parallels Foucault's description of Bentham's panopticon in terms of the practices- discipline and punishment- and the means-surveillance, it does present a reverse effect by standing as a system for provoking rather than preventing crime. Because people are observed possibly at all times, they commit crimes.

Before the migration of Iskender and his parents to London, the story calls attention towards their migration to Istanbul. It is stated also that the family is of Kurdish origin. This is of crucial importance in terms of identity and power relations. The author of the novel Honour, Elif Şafak', states in a column in the Guardian newspaper: "It is hard to be an Armenian in Turkey. Or a Kurd, or an Alevi, or gay, or a conscientious objector, or a Jew, or a woman, or somebody who just doesn't happen to agree with what's happening in the country... An "ideology of sameness" dominates the land. That ideology is shaped by Turkish nationalism, Islamism and authoritarianism blended with machismo and patriarchy. The tension in politics permeates all aspects of daily life."The exclusion of Kurdish community from Turkish society marks a rupture within national identity. Paul (1998) reveals the discrimination against Kurds who have suffered the most to date from Turkey's economic reforms. When Kurdish villagers migrate to urban environments, they are arguably the least likely to find employment within the city. 
Panopticons Migrate too and Give Birth to Criminals: A Case Study of a Turkish Muslim "Sultan" in Elif Şafak's Honour*

In addition, looking back at the history of the Turkish law, it can be noted that in the 1926 Penal Code, there is no use of the term tecavuz which means "rape" to refer to the crime of violating a woman's body against her will. There exists the word; however, "Irz" which stems from the root meaning "consent" and signifies "honour/ purity/chastity" (Parry, 2006). So, a woman's body is not perceived as a mere physical entity, but rather as a symbolic text which culturally significant rhetoric encompasses the realm of the individual. The penal Turkish code did not include "rape" as a crime "against sexual inviolability" until the year of 2004. The mentioned dates are relevant to this study because Esma's letter that marks the introduction of Şafak's novel was written in 1992 in London, England. And, the story itself that Esma narrates throughout the text of Honour has its beginning in 1945 in a village near the Euphrates. Therefore, the temporal line of the plot falls within the context of having Turkish women being considered by law as a property/ possession of family honour. This needs to be taken into consideration for an authentic interpretation of the events taking place within the novel.

As for the religious context of the text, the main question relevant to the feminist and legal aspect of the analysis is: Can Islamic law force a woman to marry someone she does not choose with her own will? The question brings the issue of justice in the Islamic government. Based on the Qur'an that is regarded as the original book of Islam, it is stated that "O ye who believe! Stand out firmly for justice, as witnesses to Allah, even as against yourselves, or your parents, or your kin, and whether it be against rich or poor: for Allah can best protect both." Hence, a yearning for fairness has been made clear by Islamic law. Also, turning to the attitude of Mohamad (the messenger of Islam) towards his own daughter, he says: "Fatima is part of me. Whatever upsets her upsets me, and whatever harms her harms me."2These Islamic sources ${ }^{3}$ bring forward the conclusion that honor killings are banned by Islam law and that they stand today as an example of how a religion comes to be manipulated by its followers. In the honor killing situation, this explains the misconception about Islamic doctrine being an accomplice in crimes committed against women's bodies.

Hence, the emphasis should be on the Muslim panopticon ${ }^{4}$ that uses a tribal/traditional mind to reinforce patriarchal ideology through a surveillance task that is carried out by the name of the disciplined term of "power,"'Allah." In Şafak'snovel, the narrative exposes how a Muslim Turkish-Kurd migrant community is male -controlled and how this exact condition of being dominated by highly contrasting gender hierarchies comes to determine the lives of not only women, but also men. Because the story deals with an honor killing that takes place within the circle of a Turkish community, family issues are viewed as part of the private institutions against which no voice- feminine, to be exact- can dissent publicly. (Marshall, 2013). Therefore, it can be said that the narration of the novel through the voice of the honour killer's sister, Esma, is a subversive strategy that destabilizes the literary form from within. "But I had to tell the story, even if only to one person. I had to send it into some corner of the universe where it could float freely, away from us" (1).This reflects that abusive violence against women cannot be healed unless the silenced feminine voices are given the opportunity to speak about their lives in their own words.

In the case of Şafak's novel Honour which was translated into Turkish as Iskender, the change in titles reflects that the text itself is a product of market surveillance and its disciplinary power, that of local and international markets. The multicultural aspect and the Orientalist tone that lie within the term "Honour" gives it a good appeal to an international audience. However, this may not be applicable to local Turkish markets where the name of the protagonist stands as the title in most novels and films set in rural environs.

2 The hadith has been examined by Islamic historiographers across various Islamic sects using the method of Isnad-thorough examination through chains of transmission. The result is an overall agreement that the hadith is reliable.

3 To avoid deviance from the main argument of the study, only the Quran is offered as an Islamic source in this article.

$4 \quad$ See "A Girl in the River: The Price of Forgiveness"

American Research Journal of English and Literature

Page 3 
Panopticons Migrate too and Give Birth to Criminals: A Case Study of a Turkish Muslim "Sultan" in Elif Şafak's Honour*

The male protagonist, Iskender, is raised in a small Turkish village, and then migrates with his parents to England where a new reality bifurcates his unifying perception of national and ethnic identities. In the absence of his father from the house, he sees, with the eye of a Turkish villager man, family's honor as his new responsibility. Iskender's father is not present in the family due to his free act of abandoning home in search of another new one with a dancer. By so doing, he affirms his unlimited freedom and his Turkish "manliness." An inheritance that is passed on to the older, yet still young, son in the form of a heavy burden placed upon the shoulders regarding the honor of family's female members. "Not everyone would understand this, but their honor was all that some men had in this world. The rich could afford to lose and regain their reputation, buying influence as perfunctorily as ordering a new car or refurnishing their mansions, but for the rest of the world things were different. The less means a man had, the higher was the worth of his honor" $(153,154)$.This stands as one of the reasons that explains how the discovery of his mother's romance provokes Iskender to commit a crime against the one he considers to be the most beloved in his life. It is later in jail that Iskender regrets the act of "honor killing" ignorant of the fact that his victim has an identical twin. It is none other than his aunt Jamila who dies at his hands.

Despite his rejection of $b a b a$ 's abusive figure, Iskender incarnates it when he learns about the traditional code to carry on in face of his mother's romance. "[...] in an act of honour killing. Iskender Toprak stabbed Pembe Toprak in front of the family home on Lavender Grove. It is claimed that the 33-year-old mother of three had an extramarital affair. Neighbours said, though they remained married, Adem and Pembe Toprak no longer lived together. But when the father is absent like that the mother's honour is guarded by the eldest son [...]" (71, 72). Iskender affirms his belief that "human nature being what it is, we hate most those we love most" (103). In Foucauldian terms, this is regarded as dynamic normalization because Iskender ends up acting as his father for fear of being caught up by Turkish Muslim community as not "man" enough to apply the standards of honor on women who in his uncle's words "did not have honor. Instead, they had shame. And, as everyone knew, shame would be rather poor name to bear" (16). Iskender has internalized communal surveillance to a point his own thoughts become enslaved to obey the master rules of the native land because as he believes "people were gossiping. Where there's smoke, there's fire" (50).However, there is no evidence in the text that gossip about Pembe ever existed back home in the village or even within the migrant community in London, England. The power of communal panopticon marks its full presence through governance of the family realm of Turkish Muslim migrants.

In Şafak'stext, the bond between mother and son is rendered secondary in face of the agency of a new bond which links control over women's body to the very notion of manliness as dictated by the traditional value system. The imbalance in power relations is reflected throughout the plot in economic terms. For example, Iskender's uncle is able to perpetuate the Turkish tradition of honor killing by controlling the financial situation of Iskender's family. He replaces the figure of the absent father and gets easily to make out of the older son, Iskender, a robotic means that physically enforces his conservative and patriarchal ideology regarding women's body and sexuality. Therefore, Iskender's crime against his own mother is not persecuted in the name of honor as much as in the name of obedience to communal surveillance. Clearly indicated in his father's statement:"a man who had been cheated of the honor that was his due was a dead man. You could not walk on the street anymore, unless you got used to staring at the pavement. You could not go to a tea house and play a round of backgammon or watch a football match in the beer house. Your shoulders would droop, your fists would be clenched, and your eyes would sink in their cavities, and your entire being would be a listless mass, shrinking more and more with every rumor. No one would pay heed to you when you spoke; your word would be no more valuable than dried dung. The cigarette you offered would be left unsmoked, the coffee you drank bitter to the end. You would not be invited to weddings, circumcision or your engagements, lest you bring your ill luck with you. In your own corner and surrounded by disgrace, you would dry up like a desiccated fruit" (154). 
Panopticons Migrate too and Give Birth to Criminals: A Case Study of a Turkish Muslim "Sultan" in Elif Şafak's Honour*

This panopticon has created the scene of a criminal and a victim. Then, ironically that same panopticon has punished the "disciplined" criminal with what he fears to undergo, in the first place,in case he does not conform to discipline.

Based on the Foucauldian panoptic model, the presence (or power of presence) of a single guard is considered sufficient for the maintenance of subjects in order. Iskender's uncle Tariq is the one to take up the role of the guard in the novel. As it is impossible for him to watch Iskender at all times and in all places, he assures that his nephew internalizes the powerful gaze of communal institution. For Foucault, this point is key because the disciplinary apparatus of panopticism cannot function efficiently without having subjects first assimilate to the subjugation of surveillance. And this embodies the Foucauldian belief that "discipline is a political anatomy of detail" (Foucault, 139). The uncle looks meticulously at the little details in Iskender's life in order to dominate it. As for Iskender, he exemplifies "the state of conscious and permanent visibility" as his body readily assumes punishment by the guard "his uncle" and the invisible power of the greater system "the community."

Before entering a prison cell and experiencing solitude in its material form, Iskender is placed already in many cells that "are like so many cages, so many small theatres in which each actor is alone, perfectly individualized and constantly visible [...] Visibility is a trap" (Foucault, 200). Hence, Iskender's body is caught up in an unverifiable power situation. And for that, Iskender becomes the guard of his own imprisonment as he constantly exercises surveillance over and against himself. He enslaves himself to community and traditional culture which are represented by the theme of honor. This is "the power of mind over mind" (Foucault, 206).And, this reflects how "Man is born free, and everywhere he is in chains. One man thinks himself the master of others but remains more of a slave than they are" (Rousseau, 1762).

On the other hand, Iskender does not apply conservative sexual codes on his British girlfriend. In fact, it is at the age of sixteen that he impregnates her. Paradoxically enough, he punishes his mother for what he saw as an "illicit affair." Iskender's confession goes as follows:

"I had stabbed her once on the right side of the chest. That would show her how grave her sin was" (247).

The hypocrisy seen in Iskender's judgment affirms that his violence is not an action based on the belief of honor codes, but rather it is a blind reaction triggered by his own need to maintain a status of manhood, and therefore of power, within the migrant community. The means to such an end can come no stronger than launching one's authority by wiping out the state of shame from within one's family.

Furthermore, Iskender lives in a state of regret during the time spent in jail. "We, the scumbags of the earththe wicked, the fallen" (135).This image contradicts that present among men who usually commit honor crimes. This again brings up the question of Iskender's primary motivation to kill his own mother. If it were a faith in the popular belief of honor, the likely effect Iskender would develop is resentment for having lost honor- as seen in other male "honor killers"-; however, the subsequent feelings Iskender expresses later on are those of regret and shame of his own doing. The logical explanation comes in his failure to assert his individuality in face of the communal panopticon that aroused in him the false perception about having to save women's honor by killing their bodies of shame. His regret turns him into a suicidal who persecutes himself on a daily basis with the memories of the mother he killed. "Then, one night my mother came to me. Her ghost an apparition. Whatever you call it. I could smell her hair. It was that real. She stayed with me the entire night. Her face. Her eyes. I sobbed like never before. After that, I began to change and am a different man today" (139).

After being released from the British jail, Iskender's attitude reveals the liberation he reaches in absence of communal panopticon. His transformative behavior is marked by the openness for dialogue and healing. He no longer links saving women's honor to being a man. Instead, his wish is centered on seeking love and being loved by finding a wife who would have the "map of [his] soul drawn on into her palm" (101). 
Panopticons Migrate too and Give Birth to Criminals: A Case Study of a Turkish Muslim "Sultan" in Elif Şafak's Honour*

It is important to mention the role of the linguistic factor as well in relation to Iskender's integration in British society. The protagonist lacks both self- and public-education. His environment (mother/community) helps him to master the Turkish language at the expense of English which in his case is limited to slang- "cockney words." This explains also why Iskender does not integrate properly in British society, and why he confines himself to kinship. Even his choice of friends is limited to Kurdish, Turkish, and Arab guys- and more specifically, to the ones who are members of the boxing club. This reveals that Iskender is living inside the communal panopticon which, through surveillance, easily manages to influence his actions. Iskender perpetuates through honor killing the ideological assertion of Turkish masculine authority.

In the novel, Iskender is viewed by his sister, Esma, first as a criminal and then as a brother (2). He stands as the stereotype of a cold-hearted Turkish Muslim man who sees honor in killing a woman for the sake of her honor. Esma asserts her claims by narrating how she is abused physically by her older brother in her trials to condemn his irrationally controlling behavior over feminine figures in the family. However, Iskender has been adored by his mother, Pembe, since childhood and has been cherished as an emperor even when his nature is more emotionally distant and domineering. The Oedipus complex is directly linked also to honor killings (Demir, 2012). "Her sultan, her lion, the apple of her eye" (337).Iskenderis the subject of Pembe's prayers even in her dying moments. This brings in question a key topic: education. Thanks to her father's insistence on education, Pembe goes to elementary school in the rural Turkish village in which she is born and raised. "[...] unlike the other eight-year-old girls in her village, she [Pembe] and Jamila went to school (10). This means that Pembe is endowed with knowledge through an education system that functions within the power of a patriarchal society. Pembe internalizes the "natural" superiority of men over women which human knowledge, in its limitations, cannot reach to understand. And for that, she shares with her daughter Esma the importance of not questioning what has already been decided by "God."

This implies that the subject of honor code is continued to this day not only through the assertive act of this ideology carried out by means of men killing women who do not respect the code, but also through the very act of escape which women seek when dealing with sexuality, womanhood, and relationships. Pembe is "the woman with endless superstitions" who has limited her communicative power to a series of rules and taboos (340). This explains why Esma is not able to have a conversation with her mother anymore and affirms her belief regarding the monitoring behavior of boys that is carried by only one intention, giving girls more and more warnings.

With Esma, the voice changes from that of accepting the status quo as an inheritance to that of justice and emancipation from essentialist gendering. Her acquirement of knowledge from British schools functions under an Western power system in which the honor code is simply absent. But Iskender is asked to act to the level of an emperor. And by that, his main function is to transform an historical ideology into a cultural stereotype (Barthes 112). This experience will solidly place Iskender's life in England within a marginalized sphere and will make Pembe complicit in the communal panopticon plan that values the male figure. Seen from that angle, the Turkish mother is the creator of her honor killer. The text reveals that the victim's double, Pembe's twin, is the one to die from the crime. Though silenced in terms of her relationship with Iskender, her punished body speaks volumes about the rules inscribed within the various institutions of power.

\section{CONCLUSION}

Using the Foucauldian model, this paper has analyzed the various cultural and religious elements that come into play during the process of normalizing crimes against women in order to save their honor. 
Panopticons Migrate too and Give Birth to Criminals: A Case Study of a Turkish Muslim "Sultan" in Elif Şafak's Honour*

Not being well-integrated in the host country's society, England, the protagonist in Şafak's novel, Iskender, is caught up within the communal surveillance that travels alongside his fellow migrants and is blind of the broader social surveillance. The well-established British panopticon falls behind the displaced migrant panopticon. The later stands as the control system that disciplines members of the community using channels of traditional thought as the norm to which each individual is assimilated. This impedes any attempt of change from taking place for fear of being condemned to lose "home" identity.

The narrative calls for a critical thinking of the established traditional norms in today's Turkish society. An everlasting change cannot occur if women are always on the side of fight for their rights when they are unconsciously propagating the persistence of injustice completed against them. This is seen in the novel with women's role as mothers who discriminate in their treatment to their sons and daughters. "Why do you give such privileges to him just because he's a boy? You do this all the time" (256). "God cut women and men from different fabrics, [...] women from the lightest fabric, which shows every speck of dirt; men from dark cloth, which doesn't stain. Because of this, unchaste women will be discovered and separated from the rest" (90). By not allowing their girls to enjoy the same degree of freedom granted to boys, women maintain a key role in sharpening masculinities that will turn into misogynic and criminal practices in the name of saving the honor of the family.

As a final note, the only male character that appears to have escaped the communal panopticon is Iskender's brother, Yunus. He appears fully integrated within the new British society. Despite his limited socializing choices, Yunus establishes contacts from outside the community, yet he still shows interest in connecting with his family members, an indicator of respect to traditional values of Turkey's rural society. Accordingly, Yunus embodies the model of convivencia ${ }^{5}$ for not judging other people based on their differences- regardless of how extreme this difference might appear. His interest and work in music is the metaphor of bringing harmony into each other's lives by understanding and not only accepting our differences, and by establishing bonds of unity because of this difference rather than despite of this difference. "While Iskender wanted to rule the world, Esma wanted to change it totally, Yunus had only one wish - to understand it. That's all” (29).

\section{REFERENCES}

1. Atabekyan, A. (2013) The case of the Turkish Family in the novel 'Honour'. MA thesis, Humboldt University.

2. Barthes, R. Mythologies. (1972) New York: Hill and Wang.

3. Demir, F. (2012) "A view on the relation of mother-son in the context o fan honour killing in Elif Shafak's novel Iskender". Turkish Studies, 7(1), 849-857

4. Foucault, M. (1995) Discipline and Punish: The Birth of the Prison. Sheridan, A. (Trans.). New York: Vintage Books.

5. Kafka, F. (1976) “In the Penal Colony," W. and E. Muir (trans.), Kafka: The Complete Stories, Glatzer (ed.), New York: Schocken.

6. Kara, M. A. (2007) "Applicability of the principle of respect for autonomy: the perspective of Turkey." J Med Ethics, 33 (11)

7. Kreissl, R. \& Wright, D. Surveillance in Europe. Routledge, 2014

8. Marshall, G.A. (2013)Shaping Gender Policy in Turkey: Grassroots Women Activists, the European Union, and the Turkish State. New York: SUNY Press.

5 Convivencia means peaceful coexistence in Spanish.

American Research Journal of English and Literature

Page 7 
Panopticons Migrate too and Give Birth to Criminals: A Case Study of a Turkish Muslim "Sultan" in Elif Şafak's Honour*

9. Parry, J. T. (ed.). (2006) "Evil, Law and the State: Perspectives on State Power and Violence." At the interface/ Probing the boundaries, 24.

10. Rousseau, J.J. (1782). Of the Social Contract, or Principles of Political Right. G.D.H. Cole (trans.)

11. Shabbar, S.M.R. (2014) Story of the Holy Ka'aba and Its People. Raleigh: Lulu Press Inc.

12. Shafak, E. (2013)Honour. London: Penguin Books Ltd.

13. _-_ . "In Turkey we can't even laugh a tour politicians any more." The Guardian, 5 May 2016, Web. Access 10 October 2016.

14. Sturken, M. and Lisa Cartwright. Practices of Looking: An Introduction to Visual Culture.

15. New York: Oxford University Press, 2001.

16. The Qu'ran. Self-translated from the Original Arabic text.

17. White, P. (1998) “Economic marginalization of Turkey's Kurds: The failed promise of modernization and reform." Journal of Muslim Minority Affairs, 18 (1),139-58

Citation: Nour Seblini, "Panopticons Migrate too and Give Birth to Criminals: A Case Study of a Turkish Muslim "Sultan" in Elif Şafak's Honour*" American Research Journal of English and Literature, vol 4, no. 1, 2018, pp. 1-8.

Copyright (c) 2018 Nour Seblini, This is an open access article distributed under the Creative Commons Attribution License, which permits unrestricted use, distribution, and reproduction in any medium, provided the original work is properly cited. 